\title{
Úskalí při interpretaci plazmatické koncentrace natriuretického peptidu typu B
}

\author{
Radka Hazuková, Miloslav Pleskot \\ I. interni klinika, Fakultní nemocnice Hradec Králové, Univerzita Karlova v Praze, \\ Lékařská fakulta $v$ Hradci Králové, Česká republika
}

\section{ÚVOD}

V nedávno publikované kontrolované studii kolektivu Jakubíka a spol. byl testován vliv vysokého krevního tlaku a hypertrofie levé komory srdeční na plazmatickou koncentraci natriuretického peptidu typu $\mathrm{B}$ (BNP). ${ }^{(1)}$ Cílová skupina pacientů měla minimálně středně těžkou esenciální arteriální hypertenzi s hypertrofií levé komory srdeční nebo bez hypertrofie levé komory srdeční. Kontrolní skupina byla tvořena zdravými dobrovolníky. Nikdo neměl systolickou srdeční dysfunkci ani významnou renální insuficienci. Autoři v závěru konstatují, že potvrdili vliv krevního tlaku a hypertrofie levé komory na plazmatickou koncentraci BNP. ${ }^{(1)}$

Citovaná studie je nesporně zajímavá a závěry Jakubíka a spol. podporují platnost již dřive prokázaných údajů. Přesto má uvedená práce zásadní limitaci, kterou nesmíme ponechat bez povšimnutí. Obecně platným pravidlem je, že koncepce každé studie vychází $z$ dobré znalosti problematiky. Přestože $\mathrm{k}$ hlavním piliřům práce Jakubíka a spol. patří otázka BNP, autoři přinejmenším nedocenili důležitost dosavadnich poznatků o BNP. Achillovou patou Jakubíka a spol., ale i některých dalších tuzemských a zahraničních autorů, je oblast fyziologie a patofyziologie BNP. ${ }^{(1-3)}$

Hlavním cílem našeho sdělení je proto upozornit čtenáře na nezbytnou opatrnost při interpretaci výsledků plazmatických koncentrací BNP. V první části stručně připomeneme základní poznatky o fyziologii a patofyziologii BNP, doplněné nezbytným komentářem ve vztahu $\mathrm{k}$ citované práci. Ve druhé části se pokusime konfrontovat metodický postup autorů uvedené práce, který se týká odběrů vzorků krve určených $\mathrm{k}$ analýze BNP.

\section{FYZIOLOGIE A PATOFYZIOLOGIE BNP}

BNP je biologicky aktivní hormon, jehož molekulu tvoři 32 aminokyselin. Uvedená molekula má biologický poločas 20-22 minut, nikoli 12 minut, jak uvádějí Jakubík a spol. Plazmatická koncentrace BNP je výslednicí mezi jeho produkcí a eliminací. Hlavním

Adresa: MUDr. Radka Hazuková, I. interní klinika, FN Hradec Králové, UK v Praze, LF v Hradci Králové, 50002 Hradec Králové, Česká republika, e-mail: hazukrad@fnhk.cz místem syntézy a uvolnění BNP je srdeční tkáň, zejména levá komora. Eliminace BNP probíhá enzymatickou cestou a příslušným degradačním enzymem je neutrální endopeptidáza. Hlavním stimulem pro syntézu a uvolnění BNP je tlakové nebo objemové přetížení srdce. Přesto tento známý fakt Jakubík a spol. pokládali za pracovní hypotézu.

Dalším obecně známým údajem, který je v práci Jakubíka a spol. rovněž podceněn, je rozdíl mezi tvorbou BNP u zdravého srdce a tvorbou BNP u patologicky změněného srdce. Pro vysvětlení připomínáme, že forma výskytu BNP v myokardu závisí na funkčním stavu srdce. Ve zdravých srdcích je produkce BNP malá a je vyhrazena pouze pro zvládání nouzových situací, ve kterých nedostačuje kompenzační mechanismus atriálního natriuretického peptidu produkovaného srdečními síněmi. Ke kumulaci BNP ve formě sekrečních váčků tedy u zdravých jedinců nedochází. Proto se BNP uvolnuuje do krevní cirkulace s latencí, která odpovídá době nutné pro syntézu BNP. Jiná situace nastává $\mathrm{u}$ jedinců $\mathrm{s}$ patologicky změněným či nezralým srdcem. V těchto srdcích nacházime rezervoár BNP v podobě preformovaných sekrečních váčků, který představuje vydatnou a okamžitou pomoc během přetížení kardiovaskulárního systému. Poškozené srdce tedy reaguje $z$ pohledu BNP na adekvátní podnět dvěma vrcholy jeho vyplavení - pozdním a promptním. $\mathrm{V}$ tomto kontextu je zřejmé, že $\mathrm{v}$ případě Jakubíka a spol. nelze pokládat zvolenou kontrolní skupinu se zdravými dobrovolníky za optimální.

Zásady správné interpretace plazmatické koncentrace BNP jsou ovšem daleko komplexnější a vycházejí z mnoha dalších poznatků. ${ }^{(4)}$ Hlavním $z$ nich je, že plazmatická koncentrace BNP vykazuje výraznou oscilaci, a to i za podmínek, které minimalizují fluktuaci BNP. ${ }^{(5-6)}$ Tato fluktuace plazmatické koncentrace BNP je dokonce tak velká, že při srovnání série plazmatických koncentrací BNP během jednoho dne často prokážeme statisticky významné rozdíly. ${ }^{(5,7)}$ Proto se recentně snaha mnoha pracovišt' soustředí na definici klinicky relevantní změny plazmatické koncentrace BNP. ${ }^{(6,8)}$ Obecně akceptovatelná definice takové změny plazmatické koncentrace BNP však dosud chybí. Zatím tedy nelze ani objektivně zhodnotit skutečný vliv řady identifikovaných faktorů, jež podle předešlých prací působí změnu plazmatické koncentrace BNP. Na tyto faktory ve své práci vhodně poukázal i kolektiv autorů Jakubíka a spol. Mezi 
zmíněné faktory řadíme věk, pohlaví, fyzickou aktivitu, přidružená onemocnění a jejich aktivitu, farmakoterapii a další terapeutické nebo diagnostické procedury. Ačkoliv je vliv některých $\mathrm{z}$ uvedených faktorů na plazmatickou koncentraci BNP podložen poměrně silnými důkazy, zůstává jejich skutečný účinek nejistý. Prozatím musíme považovat jejich vliv na plazmatickou koncentraci BNP minimálně za potenciálně možný. Proto se domníváme, že v každé studii založené na detekci plazmatické koncentrace BNP mají být v maximální možné míre omezeny všechny potenciální vlivy na plazmatickou koncentraci BNP.

\section{OKOLNOSTI ODBĚRU VZORKŮ BNP}

$\mathrm{V}$ textu Jakubíka a spol. existuje mnoho důkazů o tom, že postup při odběru a analýze vzorků BNP nebyl standardizován. Navíc je jisté, že bližšśi popis okolností odběrů vzorků BNP chybí. S jistotou se od autorů dozvídáme jen část nezbytných informací:

1. „k analýze BNP byla užita imunofluorescenční metoda Centaur Bayer“,

2 . „u většiny pacientů byla vysazena antihypertenzní medikace 3-5 dnů před vyšetřením“,

3. „krev byla odebírána do zkumavky s činidlem EDTA“,

4. „odběr BNP byl proveden po 15 minutách od uvedení pacienta do polohy vleže“.

Zatímco první tři údaje lze $\mathrm{z}$ faktického hlediska považovat za uspokojivé, věcná hodnota čtvrtého je zanedbatelná a samotná informace zavádějící. Hodnotu BNP získanou $\mathrm{z}$ odběrů krve, provedených za 15 minut od uvedení pacienta do klidu, totiž nelze považovat $z$ pohledu ustáleného stavu plazmatické koncentrace BNP za reprezentativní. Důvodem je, že ustálený stav můžeme očekávat nejdřive za 3-5násobek biologického poločasu, což je v případě BNP minimálně za 60 minut od uvedení pacienta do stabilizované polohy.

Upřesnění dalších nezbytných okolností odběrů vzorků BNP ponechal kolektiv autorů na fantazii čtenáře. Tato nepřesnost je poněkud odvážná, zejména $\mathrm{v}$ kontextu s údaji, které mohou významným způsobem modifikovat interpretaci získaných hodnot BNP („při diagnostických nejasnostech byl proveden test se zátěží infuzí fyziologického roztoku“, „měření krev- ního tlaku rtutovým sfygmomanometrem“). V textu chybí komentář i mnoha dalších, zdánlivě nepodstatných okolností (např.: př́ijem stravy a tekutin, venepunkce, způsob vlastního odběru vzorků krve včetně údajů o případném proplachu, zaškrcení či nezaškrcení paže a případné eliminaci stagnující krve, způsob uchování a způsob transportu vzorku, doba, za kterou byl vzorek analyzován a další).

Souhrnně lze konstatovat, že alespoň ta část protokolu studie, která se týká odběrů vzorků BNP, je v práci Jakubíka a spol. naprosto nedostatečná.

\section{ZÁVĚR}

I přes uvedené výhrady, Jakubík a spol. dospěli ke stř́idmému závěru a konstatují obecně uznávaný fakt, že krevní tlak má vliv na plazmatickou koncentraci BNP. Přesto by autoři studií, které jsou založeny na stanovení plazmatické koncentrace BNP, měli důsledněji respektovat dosavadní poznatky o fyziologii a patofyziologii BNP.

\section{LITERATURA}

1. Jakubík P, Janota T, Wichterle D, a spol. Mưže závažná esenciální hypertenze zpo̊sobit vzestup BNP vedoucí k falešné diagnóze srdečního selhání? Cor Vasa 2006; 48:48-54.

2. Molhoek SG, Bax JJ, van Erven L, et al. Atrial and brain natriuretic peptides as markers of response to resynchronisation therapy. Heart 2004;90:97-8.

3. Rousseau MF, Gurné O, Duprez D, et al. Beneficial neurohormonal profile of spironolactone in severe congestive heart failure. J Am Coll Cardiol 2002;40:1596-601.

4. Hazuková R. Patofyziologie natriuretického peptidu typu B. Lék Zpr LF UK Hradec Králové 2005;50:237-43.

5. Bruins S, Fokkema MR, Romer JWP, et al. High intraindividual variation of B-type natriuretic peptide (BNP) and aminoterminal proBNP in patients with stable chronic heart failure. Clin Chem 2004;50:2052-8.

6. Hazuková R, Pleskot M, Vojáček J, Čermáková E. B-typ natriuretický peptid a toleranční interval pro stanovení klinicky významné změny. Vnitř Lék 2005;51:1199-200 [Abstrakt].

7. Hazuková R, Vojáček J, Pleskot M, et al. B-type natriuretic peptide and temporary right ventricular pacing in chronic biventricular pacing. J Heart Dis 2005;4 (Suppl 1):131 [Abstract].

8. Fraser CG. Quality specifications for imprecision of B-type natriuretic peptide assay. Clin Chem 2005;51: 1307-8. 